\title{
Organizacja prokuratury powszechnej według ustawy z 20 lipca 1950 r. o Prokuraturze Rzeczypospolitej Polskiej
}

\section{MODELE PROKURATURY W UJECIU HISTORYCZNYM}

W zależności od zakresu kompetencji i struktury organizacyjnej w XIX-wiecznej Europie wykształciły się dwa podstawowe modele prokuratury: francuski i niemiecki1.

Według modelu francuskiego prokuratura była organem nadzoru ze strony władzy wykonawczej (rządu) nad prawidłowym funkcjonowaniem całego wymiaru sprawiedliwości. Takie ukształtowanie funkcji prokuratury wymuszało jej bardzo szerokie kompetencje, przy czym na plan pierwszy wysuwała się współpraca z sądami i innymi organami współpracującymi z wymiarem sprawiedliwości, zaś ściganie przestępstw schodziło na plan dalszy. Tym, co wyróżniało ten model prokuratury, był szeroki udział prokuratora w sprawach cywilnych oraz podporządkowanie mu w całości fazy wykonywania kary. W konsekwencji prokuratura stanowiła organ pośredniczący między rządem a niezawisłym sądownictwem, pozostający w stosunku nadrzędności do sądu i w związku z tym istotnie ograniczającym jego niezawisłość. Prokuratura podporządkowana była ministrowi sprawiedliwości, który jednocześnie wykonywał funkcję prokuratora naczelnego².

Późniejszy historycznie od modelu francuskiego był model niemiecki. Wyróżniało go to, że prokuratura była w zasadzie wyłącznie organem państwa do ścigania przestępstw. Do kompetencji prokuratury należało w głównej mierze postępowanie przygotowawcze w sprawach karnych i funkcja oskarżyciela publicznego w tych

${ }^{1}$ M. Łysko, Prokuratorski nadzór ogólny w Polsce w latach 1950-1967, Białystok 2006, s. 23.

2 S. Włodyka, Organizacja wymiaru sprawiedliwości, Warszawa 1963, s. 223-224. 
sprawach. Poza zakresem jej zainteresowania pozostaje faza wykonywania kary. Relacja między prokuraturą a sądownictwem jest oparta na zasadzie równorzędności. Model niemiecki, podobnie jak francuski, przewiduje podporządkowanie prokuratury ministrowi sprawiedliwości ${ }^{3}$.

Odmiennie cele i zadania prokuratury postrzegano w państwach socjalistycznych, gdzie działalność aparatu prokuratorskiego miała polegać przede wszystkim na zapewnieniu praworządności działania administracji i jednolitego przestrzegania prawa. Prawo uważano za podstawowy instrument realizacji polityki państwa socjalistycznego, gdyż regulowało ono zadania organów państwowych i innych jednostek organizacyjnych oraz środki służące realizacji tychże zadań4.

$\mathrm{Za}$ inicjatora koncepcji prokuratora jako gwaranta praworządności uznano Lenina ${ }^{5}$. Według Lenina zasada praworządności jest bezpośrednim wyrazem samej istoty socjalizmu. Skoro w warunkach władzy ludowej budującej socjalizm prawa obowiązujące nie są narzucane większości społeczeństwa przez mniejszość, lecz są wiernym sformułowaniem woli i interesów szerokich mas ludu pracującego - to aparat państwowy, będący na usługach władzy ludowej, powinien bezwzględnie szanować wolę swego mocodawcy - ludu pracującego. Dlatego w państwie ludowym, realizującym ustrój sprawiedliwości społecznej, w przeciwieństwie do państwa burżuazyjnego, istnieją szerokie możliwości coraz pełniejszego realizowania zasady praworządności ${ }^{6}$.

Realizacja praworządności ludowej w państwie ludowym była kwestią pryncypialną. Powinna się opierać na respektowaniu zasady równości wszystkich wobec prawa. Oznaczało to, że postulat ścisłego przestrzegania prawa odnosi się w równej mierze do wszystkich obywateli i nie ma miejsca na faktyczne (pozaprawne) uprzywilejowanie pod tym względem pewnych grup czy jednostek ${ }^{7}$.

Lenin silnie podkreślał odrębność prokuratury od innych organów państwowych i jej niezależność w działaniu. Chodziło tu przede wszystkim o odrębność od organów władzy i administracji, choć również o odrębność od sądu.

W zakresie odrębności prokuratury od innych organów państwowych i administracji należy odróżnić organy terenowe od organów centralnych. W założeniu

${ }^{3}$ Ibidem, s. 224.

${ }^{4}$ M. Jaroszyński, M. Zimmerman, W. Brzeziński, Polskie prawo administracyjne. Część ogólna, Warszawa 1956, s. 443.

${ }^{5}$ M. Łysko, Prokuratura Polski Ludowej na tle założeń prokuratury typu socjalistycznego, „Miscellanea Historico-Iuridica" 2005, t. 3, s. 82.

${ }^{6}$ A. Burda, Na straży praworządności ludowej [w:] I. Druski (red.), Prokuratura PRL w latach 1950-1960, Warszawa 1960, s. 7.

7 Ibidem, s. 8.

8 W.F. Dąbrowski, O leninowskiej koncepcji prokuratury, „Ruch Prawniczy, Ekonomiczny i Socjologiczny" 1963 , z. 2, s. 4. 
Lenina prokuratura w żaden sposób nie mogła być zależna od organów terenowych. Organy terenowe nie powinny mieć nawet pośredniego wpływu na prokuraturę, takiego jaki można osiągnąć poprzez prawo mianowania i zwalniania prokuratorów. Nieco inaczej miała wyglądać relacja prokuratury do organów centralnych. Prokurator jako jeden z naczelnych (lecz nie najważniejszy) organów władzy państwowej musi być podporządkowany temu ostatniemu. Podporządkowanie to może być bezpośrednie lub pośrednie.

Odrębność prokuratury od sądu, po pierwsze, sprowadzała się do różnic organizacyjnych. Prokuratura według Lenina powinna być zbudowana na zasadzie hierarchicznego podporządkowania organom centralnym. Prokuratorzy mieli pochodzić z nominacji prokuratorskich instancji centralnych i tym instytucjom mieli być podporządkowani. Po drugie, odrębność przejawiała się w zakresie kompetencji obu tych organów ${ }^{10}$.

Pierwszą prokuraturą typu socjalistycznego była utworzona na mocy ustawy z 28 maja 1922 r. o nadzorze prokuratorskim prokuratura Związku Radzieckiego ${ }^{11}$. Prokuratura utworzona została na żądanie Lenina, twórcy niektórych jej zasad. Radziecka prokuratura powszechna była podporządkowana Komisariatowi Ludowemu Sprawiedliwości, tj. ówczesnemu Ministerstwu Sprawiedliwości. Na czele prokuratury stał Komisarz Ludowy Sprawiedliwości w charakterze Prokuratora Republiki. W koncepcji leninowskiej Komisarz Ludowy Sprawiedliwości w stosunku do pozostałych członków rządu zajmował stanowisko szczególne, łącząc funkcję komisarza (ministra) z funkcją Prokuratora Republiki. To jego szczególne stanowisko wobec innych członków rządu wynikało z faktu, że będąc członkiem rządu i Rady Komisarzy Ludowych, jako Prokurator Republiki wyposażony został w uprawnienia pozwalające nadzorować legalność działania i decyzji wszystkich innych resortów ${ }^{12}$. Również następna ustawa radziecka o prokuraturze, z 17 grudnia 1933 r., podporządkowywała prokuraturę Radzie Komisarzy Ludowych, która miała prawo uchylania i zawieszania zarządzeń Prokuratora ZSRR. W wyniku działań centralizacyjnych prokuratura radziecka w 1936 r. została wyodrębniona z zakresu działania republikańskich komisariatów ludowych sprawiedliwości i podporządkowana Prokuratorowi ZSRR, który podlegał Radzie Najwyższej ZSRR $^{13}$.

\footnotetext{
9 Ibidem, s. 5.

10 Ibidem, s. 7-8.

11 J.S. Konic, Uwagi ogólne o umiejscowieniu prokuratury w systemie organów państwowych, „Nowe Prawo” 1957, nr 11, s. 27.

12 Ibidem, s. 27-28.

13 Ibidem, s. 28-29.
} 


\section{WPROWADZENIE SOCJALISTYCZNEGO MODELU PROKURATURY I JEJ MIEJSCE W SYSTEMIE ORGANÓW PAŃSTWA}

Organizacja prokuratury polskiej, a zwłaszcza zakres jej kompetencji i zadań uległy w latach powojennych zasadniczym zmianom. Po zakończeniu II wojny światowej prokuratura była oparta na zasadach obowiązujących 1 września 1939 r., tj. na zasadach właściwych dla kapitalistycznego typu prokuratury, ze szczególnym uwzględnieniem wzoru niemieckiego. Pod względem organizacyjnym prokuraturę cechowało ścisłe powiązanie z systemem sądowym, co znajdowało wyraz w dostosowaniu organizacji hierarchicznej prokuratury do organizacji hierarchicznej sądów (prokuratura sądu okręgowego, apelacyjnego i Sądu Najwyższego) oraz podporządkowaniu jej ministrowi sprawiedliwości, który był Naczelnym Prokuratorem ${ }^{14}$.

W latach 1944-1950 przeprowadzono reformy cząstkowe mające na celu dostosowanie aparatu prokuratury do wymagań, jakie stawiała rzeczywistość okresu powojennego, z uwzględnieniem zadań wynikających z nowego ustroju politycznego i społecznego ${ }^{15}$.

Gruntownej reformy dokonano ustawą z dnia 20 lipca 1950 r. o Prokuraturze Rzeczypospolitej Polskiej ${ }^{16}$, która wprowadziła leninowski model prokuratury ${ }^{17}$. Odwołując się do leninowskiej koncepcji scentralizowanej prokuratury i opierając się na wzorcach radzieckich, prokuratura została oddzielona od sądów i wydzielona z resortu sprawiedliwości. Stała się odrębnym pionem organów państwa, formalnie podporządkowanym Radzie Państwa, faktycznie zaś - najwyższym władzom PZPR ${ }^{18}$.

Prokuraturę Rzeczypospolitej Polskiej stanowili Generalny Prokurator Rzeczypospolitej i jego organy ${ }^{19}$. Ustawa lipcowa z 1950 r. do organów Generalnego Prokuratora zaliczała: zastępców Generalnego Prokuratora Rzeczypospolitej, prokuratorów i wiceprokuratorów Generalnej Prokuratury oraz referendarzy śledczych, w województwach - prokuratorów wojewódzkich oraz podległych im wiceprokuratorów i podprokuratorów prokuratur wojewódzkich oraz w mieście st. Warszawie i w mieście Łodzi referendarzy śledczych i asesorów prokuratury, w powiatach z kolei prokuratorów powiatowych i podległych im podprokuratorów prokuratur powiatowych, referendarzy śledczych oraz asesorów prokuratury ${ }^{20}$.

Zależność prokuratury od Rady Państwa, stosownie do przepisów ustawy o Prokuraturze Rzeczypospolitej Polskiej, wyrażała się w wyłącznym uprawnieniu

\footnotetext{
${ }^{14}$ S. Włodyka, Ustrój organów ochrony prawnej, Warszawa 1968, s. 196.

15 Ibidem.

${ }^{16}$ Ustawa z dnia 20 lipca 1950 r. o Prokuraturze Rzeczypospolitej Polskiej, Dz. U. Nr 38, poz. 346.

17 L. Mazowiecka, Prokuratura w Polsce 1918-2014, Warszawa 2015, s. 113.

18 A. Lityński, Historia prawa Polski Ludowej, Warszawa 2013, s. 81.

${ }_{19}$ Art. 2 ustawy o Prokuraturze Rzeczypospolitej Polskiej (dalej: u.p.)

${ }^{20}$ Art. 7 pkt $1-3$ u.p.
} 
nadanym Radzie Państwa do powołania i odwołania Generalnego Prokuratora ${ }^{21}$. Przewodniczący Rady Państwa natomiast powoływał i odwoływał zastępców Generalnego Prokuratora ${ }^{22}$ oraz mianował i zwalniał prokuratorów Generalnej Prokuratury i prokuratorów wojewódzkich na wniosek Generalnego Prokuratora ${ }^{23}$. W dalszej kolejności należy wskazać, iż prokuratura działała zgodnie z wytycznymi Rady Państwa, a Generalny Prokurator obowiązany był do składania sprawozdań z działalności prokuratury ${ }^{24}$. W literaturze przedmiotu wskazuje się, że obowiązek składania sprawozdań z działalności prokuratury nie był realizowany w pierwszej kadencji Sejmu, tj. w latach 1952-1956 $6^{25}$. Po raz pierwszy sprawozdanie z działalności organów prokuratury zostało przedłożone Radzie Państwa 4 stycznia 1957 r. ${ }^{26}$

Podporządkowanie prokuratury Radzie Państwa wyrażało się również w tym, że Rada Państwa podejmowała uchwały dotyczące organizacji i funkcjonowania prokuratury i jej pracowników oraz określała instrukcje w zakresie współdziałania Generalnego Prokuratora i jego organów z Najwyższą Izbą Kontroli i organami kontroli społecznej ${ }^{27}$.

Przepisy ustawy o Prokuraturze Rzeczypospolitej Polskiej nie zawierały normy o podporządkowaniu prokuratury Sejmowi. Niemniej pośrednio takie podporządkowanie istniało - przez Radę Państwa, która była emanacją Sejmu. Sejm mógł więc przez nią kontrolować działalność prokuratury, a nawet dawać jej wytyczne ${ }^{28}$.

Ostatecznie zatem prokuratura w Polsce Ludowej zajmowała w systemie organów państwowych pozycję organu całkowicie wyodrębnionego i niezależnego od wszelkich organów administracji państwowej, sądownictwa i terenowych organów władzy, podporządkowanego bezpośrednio Radzie Państwa i pośrednio Sejmowi, wobec których Prokurator Generalny był odpowiedzialny za całokształt jej działalności ${ }^{29}$.

\section{ORGANIZACJA PROKURATURY}

Problematyka wewnętrznych struktur organizacyjnych prokuratur od chwili powołania ustawą z 20 lipca 1950 r. urzędu Prokuratora Generalnego była stale jednym z ważniejszych zagadnień organizacyjnych. Zawsze dostrzegano ścisłe

${ }^{21}$ Art. 5 ust. 1 u.p.

${ }^{22}$ Art. 5 ust. 2 u.p.

${ }^{23}$ Art. 8 ust. 1 u.p.

${ }^{24}$ Art. 6 u.p.

${ }^{25}$ J. Stembrowicz, Uwagi o Radzie Państwa de lege lata i de lege ferenda, „Państwo i Prawo” 1957, nr 2, s. 255.

${ }^{26}$ Ibidem.

${ }^{27}$ Art. 13, 14, 15 ust. 2.

${ }^{28}$ S. Włodyka, Organizacja..., s. 232.

${ }^{29}$ Ibidem, s. 233. 
związki między wewnętrznymi strukturami jednostek a zadaniami merytorycznymi prokuratorów ${ }^{30}$.

Organizacja Prokuratury RP określona została w Tymczasowym Statucie Organizacyjnym, przyjętym przez Radę Państwa w uchwale nr 82/50 z dnia 21 września 1950 r. ${ }^{31}$ Organizacja hierarchiczna prokuratury powszechnej była trójszczeblowa i obejmowała Generalną Prokuraturę, prokuratury wojewódzkie i prokuratury powiatowe ${ }^{32}$.

Generalna Prokuratura składała się z czterech departamentów: Nadzoru Ogólnego, Nadzoru nad Śledztwem i Dochodzeniem, Sądowego, Nadzoru nad Wykonywaniem Kary i trzech biur ${ }^{33}$. Departament Nadzoru Ogólnego prowadził oraz kontrolował i wydawał instrukcje podległym prokuraturom w zakresie nadzoru ogólnego. W skład departamentu wchodziły trzy wydziały, w tym wydział do spraw prawa pracy, sprawujący nadzór nad przestrzeganiem przepisów prawa pracy. Departament Nadzoru nad Śledztwem i Dochodzeniem obejmował cztery wydziały, rozpatrywał odwołania od postanowień prokuratorów wojewódzkich i skargi na ich czynności w toku postępowania przygotowawczego, sprawy przedłużania terminów trwania śledztw i tymczasowego aresztowania podejrzanych w toku śledztwa, nadzorował prokuratury terenowe w zakresie śledztwa i dochodzenia oraz opracowywał metody prowadzenia postępowania przygotowawczego. Departament Sądowy składał się z czterech wydziałów, których przedmiotem zainteresowania pozostawał udział prokuratury w postępowaniach przed Sądem Najwyższym w sprawach karnych i cywilnych, rewizje nadzwyczajne, analiza orzecznictwa Sądu Najwyższego oraz kontrola i instruktaż podległych jednostek prokuratury w zakresie udziału prokuratorów w sądowych postępowaniach karnych i cywilnych. Departament Nadzoru nad Wykonywaniem Kary składał się z dwóch wydziałów, których przedmiotem działania był nadzór nad wykonywaniem wyroków w sprawach karnych oraz sprawy ułaskawień. Ponadto utworzone były trzy biura: Prezydialne, Kadr i Szkolenia oraz Budżetowo-Gospodarcze ${ }^{34}$. Generalną Prokuraturę, obok Generalnego Prokuratora, tworzyli zastępcy Generalnego Prokuratora Rzeczypospolitej, prokuratorzy i wiceprokuratorzy Generalnej Prokuratury oraz referendarze śledczy ${ }^{35}$.

${ }^{30}$ H. Zięba-Załucka, Instytucja Prokuratury w Polsce, Warszawa 2003, s. 27.

${ }^{31}$ M. Chigryn, A. Zborowski, Organizacja Prokuratury PRL [w:] I. Druski (red.), Prokuratura PRL..., s. 35.

32 S. Włodyka, Organizacja..., s. 282-284.

${ }^{33}$ Ibidem, s. 282-283. W literaturze przedmiotu można też spotkać nieco inny podział organizacyjny Generalnej Prokuratury, wyróżniający siedem departamentów i dwa biura. Szerzej: M. Chigryn, A. Zborowski, Organizacja Prokuratury..., s. 35.

${ }^{34}$ S. Włodyka, Organizacja..., s. 282-283.

${ }^{35}$ Art. 7 pkt 1 u.p. 
Prokuratury wojewódzkie pod względem terytorialnym obejmowały województwa lub miasta wyłączone $\mathrm{z}$ województw (miasto st. Warszawa i miasto Łódź). Prokuratury wojewódzkie składały się z pięciu wydziałów będących odpowiednikami departamentów i biur Generalnej Prokuratury, a więc Wydziału Nadzoru Ogólnego, Wydziału Nadzoru nad Śledztwem i Dochodzeniem, Wydziału Sądowo-Penitencjarnego, Wydziału Prezydialnego i Wydziału Budżetowo-Gospodarczego. Wydziały mogły z kolei dzielić się na referaty lub rejony, według zasady podziału rzeczowego lub terytorialnego ${ }^{36}$. W skład prokuratur wojewódzkich wchodzili prokuratorzy wojewódzcy oraz podlegli im wiceprokuratorzy i podprokuratorzy prokuratur wojewódzkich, a także w mieście st. Warszawie i mieście Łodzi, referendarze śledczy i asesorowie prokuratury ${ }^{37}$.

Prokuratury powiatowe z kolei utworzone były dla powiatów lub miast stanowiących powiaty. Prokuratury dzielone były na rejony śledczo-dochodzeniowe, tworzone na zasadzie terytorialnej ${ }^{38}$. Prokuratury powiatowe stanowili prokuratorzy powiatowi i podlegli im podprokuratorzy prokuratur powiatowych, referendarze śledczy oraz asesorowie prokuratury ${ }^{39}$.

W praktyce jednak należało prokuraturę dopiero zorganizować. Zadania i trudności organizacyjne pierwszego okresu spadły na barki nielicznej początkowo kadry, przeniesionych do Generalnej Prokuratury pracowników prokuratorskich i administracyjnych byłego Departamentu Nadzoru Prokuratorskiego Ministerstwa Sprawiedliwości i byłego Biura Wykonawczego Komisji Specjalnej, a w terenie - na pracowników prokuratur apelacyjnych, okręgowych i delegatur Komisji Specjalnej. Jednostki nowej prokuratury mogły w pewnym, choć dalece niewystarczającym stopniu oprzeć swoją organizację na istniejących, mniej lub bardziej odpowiadających potrzebom, bazach kadrowych i materialnych. Taką bazą dla utworzenia Prokuratury Generalnej były, ulegające likwidacji, Departament Nadzoru Prokuratorskiego Ministerstwa Sprawiedliwości oraz Biuro Wykonawcze Komisji Specjalnej ${ }^{40}$.

Prokuratury wojewódzkie organizowały się tam, gdzie było to możliwe, na bazie prokuratur apelacyjnych i wojewódzkich delegatur Komisji Specjalnej, w końcu prokuratury powiatowe mogły w nielicznych tylko przypadkach oprzeć się o jakąś bazę, skoro prokuratur okręgowych działało od chwili ich likwidacji około 60, a liczba powiatów znacznie przekraczała 300 jednostek administracyjnych. Według danych na dzień 1 stycznia 1951 r. Prokuratura RP, obok Generalnej Prokuratury, liczyła 19 prokuratur wojewódzkich i 287 prokuratur powiatowych ${ }^{41}$.

\footnotetext{
${ }^{36}$ S. Włodyka, Organizacja..., s. 283.

${ }^{37}$ Art. 7 pkt 2 u.p.

38 S. Włodyka, Organizacja..., s. 284.

${ }^{39}$ Art. 7 pkt 3 u.p.

${ }^{40}$ M. Chigryn, A. Zborowski, Organizacja Prokuratury..., s. 35-36.

${ }^{41}$ Ibidem, s. 36.
} 
Ustawa o prokuraturze z $1950 \mathrm{r}$. była ramowa, lakoniczna i nie regulowała wielu kwestii, które powinny w takiej ustawie się znaleźć. Na przykład nie ustanawiała jakichkolwiek wymogów dla powołania na stanowisko prokuratora, pozostawiając tym samym otwartą drogę do mianowania „swoich” prokuratorów, w tym tych bez wykształcenia ${ }^{42}$. Pod koniec 1950 r. na ogólną liczbę 1332 prokuratorów 654 osoby nie miały wyższego wykształcenia, w tym 441 absolwentów kursów (tzw. prawniczych szkół średnich), a 213 osób nie miało jakiegokolwiek przygotowania ${ }^{43}$. Spośród kadry prokuratorskiej do PZPR należało 814 osób, ZSL - 49 osób, SD - 105, a 364 osoby były bezpartyjne ${ }^{44}$.

Generalny Prokurator Rzeczypospolitej, jego zastępcy, prokuratorzy, wiceprokuratorzy, podprokuratorzy, referendarze śledczy i asesorowie podlegali odpowiedzialności dyscyplinarnej według regulaminu o odpowiedzialności dyscyplinarnej, uchwalonego przez Radę Państwa na wniosek Generalnego Prokuratora Rzeczypospolitej ${ }^{45}$.

Regulamin został określony uchwałą Rady Państwa z dnia 6 września 1951 r. w sprawie regulaminu o odpowiedzialności dyscyplinarnej prokuratorów ${ }^{46}$. Wprowadził odrębną od sądownictwa powszechnego odpowiedzialność dyscyplinarną prokuratorów $\mathrm{w}^{47}$. Prokurator podlegał odpowiedzialności za przewinienie dyscyplinarne, czyli naruszenie dyscypliny służbowej oraz niewłaściwe zachowanie w służbie i poza nią ${ }^{48}$. Przez dyscyplinę służbową rozumiano sumienne i dokładne wykonywanie obowiązków służbowych oraz ścisłe stosowanie się do zarządzeń i wskazówek przełożonych, natomiast podstawą tejże dyscypliny winna być świadomość prokuratora, iż jest powołany do ugruntowania praworządności ludowej, ochrony własności społecznej, ochrony praw obywateli i do ścigania przestępstw ${ }^{49}$.

W sprawach dyscyplinarnych prokuratorów orzekały komisje dyscyplinarne przy prokuraturach wojewódzkich i Generalnej Prokuraturze w składzie trzech osób spośród sześciu członków oraz Odwoławcza Komisja Dyscyplinarna przy Generalnej Prokuraturze również w składzie trzyosobowym z grona 12 członków. Członków komisji powoływał Generalny Prokurator ${ }^{50}$. Komisje dyscyplinarne przy prokuraturach wojewódzkich rozpoznawały sprawy w pierwszej instancji wobec

${ }^{42}$ A. Lityński, Historia prawa..., s. 82.

${ }^{43}$ Ibidem, s. 80.

${ }^{44}$ W. Taraszkiewicz, Osobowa obsada Prokuratury PRL [w:] I. Druski (red.), Prokuratura PRL..., s. 54.

${ }^{45}$ Art. 16 u.p.

${ }^{46}$ Uchwała Rady Państwa z dnia 6 września 1951 r. w sprawie regulaminu o odpowiedzialności dyscyplinarnej prokuratorów, M.P. Nr A-82, poz. 1133.

${ }^{47}$ L. Mazowiecka, Prokuratura $w$ Polsce..., s. 115.

$48 \S 3$ Regulaminu o odpowiedzialności dyscyplinarnej prokuratorów (dalej: Regulamin).

$49 \S 1$ ust. 2 i 3 Regulaminu.

$50 \S 10$ i $§ 12$ Regulaminu. 
prokuratorów powiatowych, podprokuratorów, referendarzy śledczym i asesorów prokuratury powiatowej oraz wiceprokuratorów, podprokuratorów, starszych referendarzy śledczych, referendarzy śledczych i asesorów prokuratur wojewódzkich ${ }^{51}$. Komisja Dyscyplinarna przy Generalnej Prokuraturze rozpoznawała w pierwszej instancji sprawy przeciwko prokuratorom wojewódzkim i ich zastępcom, prokuratorom, wiceprokuratorom, starszym referendarzom i referendarzom śledczym Generalnej Prokuratury oraz delegowanym do Generalnej Prokuratury wiceprokuratorom, podprokuratorom, starszym referendarzom, referendarzom śledczym i asesorom prokuratur wojewódzkich i powiatowych. Odwołania od orzeczeń komisji dyscyplinarnych były rozpoznawane przez Odwoławczą Komisję Dyscyplinarną ${ }^{52}$.

W przypadku uznania, że prokurator popełnił przewinienie dyscyplinarne, można było wobec niego orzec karę dyscyplinarną w postaci: nagany, surowej nagany, odliczenia lat służby od roku do trzech lat, dyscyplinarnego przeniesienia na inne równorzędne lub niższe stanowisko służbowe, obniżenia grupy uposażenia o jedną lub dwie, wydalenia ze służby. Za przewinienia dyscyplinarne mniejszej wagi przełożony mógł udzielić podległemu prokuratorowi upomnienia. Nie można było jednak udzielić upomnienia po upływie 6 miesięcy ani wszcząć postępowania dyscyplinarnego po upływie 2 lat od popełnienia przewinienia dyscyplinarnego ${ }^{53}$.

\section{ZASADY ORGANIZACJI I DZIAŁANIA PROKURATURY}

Z usytuowania prokuratury w systemie organów państwowych oraz kierunków jej działalności wynikały podstawowe zasady dotyczące $z$ jednej strony organizacji (struktury) prokuratury, a z drugiej - jej działalności. Zasady organizacji i działalności prokuratury są wynikiem procesu historycznego. W większości przypadków, przynajmniej jeśli chodzi o nazwę, nawiązują do zasad wykształconych również w prokuraturze kapitalistycznej. Treść tych zasad jest jednak inna, zawsze ze względu na cel polityczno-społeczny, któremu ma służyć działalność prokuratury. Istnieją też zasady wyłącznie właściwe dla prokuratury socjalistycznej, np. zasada niezależności prokuratury od wszelkich organów państwowych z wyjątkiem Rady Państwa i Sejmu ${ }^{54}$.

Można wyróżnić pięć zasad określających ogólnie organizację (strukturę wewnętrzną) prokuratury: jednolitości, centralizmu, niezależności, jednoosobowego kierownictwa, hierarchicznego podporządkowania ${ }^{55}$. Zasada jednolitości, zwana

\footnotetext{
${ }^{51} \S 11$ ust. 1 Regulaminu.

$52 \S 11$ ust. 2 i 3 Regulaminu.

${ }^{53} \S 6$ ust. $1, \S 7 \mathrm{i} \S 9$ Regulaminu.

${ }^{54}$ S. Włodyka, Ustrój organów..., s. 238-239.

${ }^{55}$ Ibidem, s. 239.
} 
również zasadą niepodzielności, oznacza, iż do sprawowania specjalnego nadzoru nad przestrzeganiem prawa na terenie całego państwa powołany jest jeden organ, tj. prokuratura, działająca jako całość z Prokuratorem Generalnym PRL na czele. Zasada centralizmu oznacza, że wszystkie organy prokuratury na terenie całego kraju są podporządkowane jednemu najwyższemu organowi prokuratorskiemu, tj. Prokuratorowi Generalnemu, który kieruje całą działalnością prokuratury i jest za nią odpowiedzialny. Zasada niezależności polega na tym, że prokuratura zarówno pod względem organizacyjnym, jak i w wykonywaniu działalności nie była podporządkowana żadnym innym organom państwowym, politycznym czy społecznym z wyjątkiem naczelnych organów władzy państwowej, tj. Rady Państwa i Sejmu. Zasada jednoosobowego kierownictwa przejawiała się w tym, że na czele całej prokuratury stał organ jednoosobowy - Generalny Prokurator. Podobnie sprawa wyglądała na niższych szczeblach prokuratury, tj. na czele prokuratury wojewódzkiej stał prokurator wojewódzki, na czele powiatowej zaś - prokurator powiatowy. Zasada hierarchicznego podporządkowania polegała na tym, że organ prokuratorski stojący wyżej miał prawo wydawać organowi podporządkowanemu wiążące polecenia dotyczące kierunku i sposobu prowadzenia danej sprawy ${ }^{56}$.

Zasady działania określają ogólnie sposób wykonywania przez prokuraturę jej zadań w zakresie nadzoru nad przestrzeganiem prawa. Można wyróżnić siedem takich zasad: legalizmu, działania z urzędu, współpracy z innymi organami państwowymi oraz organizacjami spółdzielczymi i społecznymi, substytucji, dewolucji, indyferencji i jednoosobowego dokonywania czynności ${ }^{57}$. Zasada legalności polega na obowiązku podejmowania przez prokuraturę działania za pośrednictwem wszelkich stojących do jej dyspozycji środków w każdym przypadku grożącego lub dokonanego naruszenia prawa. Zasada działania z urzędu przejawia się w tym, że w razie grożącego lub dokonanego naruszenia prawa prokuratura działa zawsze z urzędu, tj. bez względu na inicjatywę jakiegokolwiek czynnika zewnętrznego. Zasada współpracy z innymi organami państwowymi oraz organizacjami spółdzielczymi jest charakterystyczna wyłącznie dla prokuratury typu socjalistycznego i wyraża się w obowiązku ścisłej współpracy z władzami państwowymi, sądami, organami kontroli państwowej, organami MO oraz w utrzymywaniu kontaktu z partiami politycznymi, związkami zawodowymi i innymi masowymi organizacjami społecznymi. Zasada substytucji rozumiana jest zwykle w ten sposób, że prokurator wyższego rzędu może zlecić dokonanie w zasadzie każdej czynności prokuratorowi niższego rzędu. Zasadę dewolucji należy rozumieć w ten sposób, iż prokurator wyższego rzędu może dokonać każdej czynności należącej do podporządkowanego prokuratora i uchylić każdą jego decyzję, Generalny Prokurator zaś może dokonać

\footnotetext{
56 Ibidem, s. 239-242.

57 S. Włodyka, Organizacja..., s. 277.
} 
każdej czynności należącej do każdego prokuratora. Zasada indyferencji oznacza, że określone zmiany podmiotowe nie mają wpływu na ważność czynności prokuratorskiej. Natomiast z zasady jednoosobowego dokonywania czynności wynika, iż każda czynność prokuratorska dokonywana jest jednoosobowo ${ }^{58}$.

\section{WNIOSKI KOŃCOWE}

Polska po II wojnie światowej znalazła się w sowieckiej strefie wpływów, co miało konsekwencje w postaci zmian ustrojowych i politycznych. Wprowadzenie ustroju socjalistycznego wymusiło przeprowadzenie transformacji całego aparatu państwowego, bowiem istniejące rozwiązania nie sprawdzały się w obliczu wymagań nowego ładu politycznego. Przełom lat 40. i 50. to czas, w którym komuniści zaczęli proces intensywnej sowietyzacji Polski. Przebudowano wówczas system naczelnych organów administracji państwowej w zakresie kierowania i zarządzania gospodarką narodową, dokonano gruntownej reformy systemu rad narodowych, przekształcając je w jednolite organy władzy państwowej ${ }^{59}$. Dokonano również zmian w zakresie zasad organizacyjnych i kompetencji prokuratury, rezultatem których było wprowadzenie socjalistycznego modelu prokuratury. Rozwiązania przyjęte ustawą lipcową nie były jednak wynikiem autorskiej pracy legislatorów, lecz stanowiły recepcję rozwiązań radzieckich przeprowadzoną w sposób mechaniczny, bez uwzględnienia polskiej specyfiki ustrojowej ${ }^{60}$. W ten właśnie sposób Polsce, podobnie jak innym krajom ,demokracji ludowej”, narzucono socjalistyczny model prokuratury ${ }^{61}$.

Prokuratura, obok aparatu bezpieczeństwa publicznego, postrzegana była przez „nową władzę" jako gwarant utrwalenia zdobyczy socjalizmu i pomimo formalnego podporządkowania Generalnego Prokuratora Radzie Państwa w praktyce ścisła zależność aparatu prokuratorskiego od instancji partyjnych powodowała, że było ono czysto teoretyczne ${ }^{62}$. Prokuratura została powołana nie tylko do ścigania przestępstw i sprawowania nadzoru nad wykonywaniem kary, ale także do sprawowania nadzoru ogólnego nad przestrzeganiem prawa przez wszystkie organy, władze i urzędy ${ }^{63}$. Prokurator - koniecznie członek partii komunistycznej - miał ściśle współpracować z komitetem partii, a prokuratury miały być aktywnymi

58 Ibidem, s. 277-280.

59 A. Burda, Na straży praworzadności..., s. 5.

${ }^{60}$ M. Łysko, Prokuratura Polski Ludowej..., s. 98.

${ }^{61}$ Socjalistyczny model prokuratury, przy zachowaniu pewnych drugorzędnych odrębności, wprowadzono w Bułgarii, Albanii, Rumunii, Czechosłowacji, NRD i na Węgrzech. Zob. M. Siewierski, Ustrój Prokuratury PRL [w:] I. Druski (red.), Prokuratura PRL..., s. 23.

${ }^{62}$ A. Drogoń, $Z$ dziejów prawa, cz. 7: Model prokuratury w systemie władzy publicznej w Polsce w latach 1944-1956, Katowice 2005, s. 168-169.

${ }^{63}$ L. Mazowiecka, Prokuratura $w$ Polsce..., s. 116. 
pomocnikami partii w walce o zwycięstwo socjalizmu ${ }^{64}$. Prokuratura stała się organem represji za prawdziwe lub rzekome czyny antypaństwowe. Panował pogląd, że prokuratura jest odpowiedzialna, by wyroki były takie, jak sobie życzy władza polityczna ${ }^{65}$. Wprowadzony przez ustawę lipcową leninowski model prokuratury znalazł swoją kontynuację w kolejnych ustawach o prokuraturze, przyjętych w 1967 i 1985 r. ${ }^{66}$ Dopiero w wyniku przemian ustrojowych 1989 r. zerwano z modelem socjalistycznym, a prokuratura stała się na powrót niezależna.

\section{THE ORGANIZATION OF THE PUBLIC PROSECUTOR'S OFFICE PURSUANT TO THE PROSECUTOR'S OFFICE ACT IN THE POLISH PEOPLE'S REPUBLIC OF 20 JULY 1950}

\section{Abstract}

The article is an attempt to show the issue of the organization of the prosecutor's office in the Polish People's Republic based on the provisions of the Act on the Prosecutor's Office of 20 July 1950. It introduced some models of the prosecutor's office, with special attention paid to the development and the principles of the socialist prosecutor's office in the Soviet Union, and these solutions were adopted then by the Polish legal system. The Act of 20 July 1950 rejected the rules of the organization of the capitalist prosecutor's office, which had been in force until then, as they were considered inconsistent with the new system of government. They were replaced by the solutions on the basis of which the prosecutor's office was separated from the Ministry of Justice and, consequently, it became an institution which was independent of all public administration bodies. Despite the fact that the regulations provided for the formal subordination of the prosecutor's office to the Council of State, communist party dignitaries in fact decided on the direction and the activity of the prosecution system. The communists needed a fully obedient institution which they could employ to achieve their goals. Consequently, the prosecutor's office, whose main task was to prosecute offences, became an institution of control and surveillance, which was aimed not only at individual citizens but also at organizations and offices. These duties were performed on the basis of the powers vested in it in the form of the so-called general supervision, and repressive punishment was to be a performance indicator. This Act, in spite of being quite general and laconic (it consisted of twenty-four sections, seven of which constituted transitional and final provisions), introduced all the elements necessary to implement a socialist prosecutor's office in Poland on the basis of Lenin's concept. The socialist model of the prosecutor's office in Poland was in force until the social and political changes took place in 1989.

Keyw ord s: socialist model of prosecutor's office, organization of prosecutor's office, Lenin

${ }^{64}$ A. Lityński, Historia prawa.., s. 80.

${ }^{65}$ Ibidem, s. 81.

${ }^{66}$ Ustawa z 14 kwietnia 1967 r. o Prokuraturze Polskiej Rzeczypospolitej Ludowej (Dz. U. Nr 13, poz. 55); ustawa z 20 czerwca 1985 r. o Prokuraturze Polskiej Rzeczypospolitej Ludowej (Dz. U. Nr 31, poz. 138). 